(7)

\title{
Impact of Economic Reforms on Social Sector of Pakistan: An Empirical Analysis
}

\author{
a Muhammad Shakeel, b Azmat Hayat \\ ${ }^{a}$ Assistant professor, Department of Economics, Government Islamia College Civil lines Lahore, Pakistan \\ Email: muhammadshakeel200o@gmail.com \\ ${ }^{\mathrm{b}}$ Assistant professor, Department of Economics, Punjab University Lahore, Pakistan \\ Email: azmathayat.eco@pu.edu.pk
}

\begin{tabular}{l}
\hline ARTICLE DETAILS \\
\hline History: \\
Accepted 22 May 2020 \\
Available Online 30 June 2020 \\
\hline Keywords: \\
Economic Reforms, ARDL, \\
Poverty, Income Inequality \\
JEL Classification: \\
B23, B29, C1O \\
\hline
\end{tabular}

DOI: $10.47067 /$ reads.v6i2.210

\section{ABSTRACT}

This study evaluates the impact of economic reforms on the social sector of Pakistan by constructing the index of economic reforms of the key sectors of the economy for the period 1971 to 2015 using ARDL. For analysis purpose two separate models have been estimated for poverty and income inequality. The results of the study reveal that economic reforms impact poverty and income inequality negatively and significantly. The negative relationship of economic reforms show that economic reforms are helpful for improving the social sector of Pakistan. Moreover, both the models also show convergence from short run to long run period. The foreign direct investment exerts positive impact on poverty and gross fixed capital has positive impact on both poverty and income inequality. The relationship between population growth and income inequality is positive and significant. Moreover, age dependency ratio and life expectancy reduces both inequality and poverty respectively in the long run. The role of crime appears to be insignificant in case of income inequality. The study suggests that government of Pakistan should formulate and implement pro poor policies and introduce reforms for providing health and educational facilitates. Furthermore, the introduction food subsidy to the poor will also be helpful in reducing the intensity of poverty and inequality in Pakistan.

(C) 2020 The authors. Published by SPCRD Global Publishing. This is an open access article under the Creative Commons Attribution-

NonCommercial 4.0

Corresponding author's email address: muhammadshakeel20oo@gmail.com

\section{Introduction}

Every country of the world is striving to achieve rapid economic growth through the development of its social sectors. As social problems like poverty and income inequality faced by an economy may retard the process of economic growth. Chambers (2006) explains poverty as shortage of income, absence of material things, poor and weak physical capacity, capabilities and finally shortage of basic necessities of life both material and immaterial. From socio-economic point of view poverty 


\section{Review of Economics and Development Studies, Vol. 6 (2) 2020, 323-337}

generates violent actions and life-threatening activities which are dangerous for the sustainability of a society (Seccombe, 2000). Poverty is a universal phenomenon and may be defined as a socio-economic deprivation (Khan, 2001). Mohsin (2013) evaluated high rate of poverty in Muslim countries as in Pakistan 24, Afghanistan 53, Indonesia 18, Iran18, Bangladesh 45, Sudan 40, Yemen 45, Algeria 23, Egypt 20 and Nigeria 70 per cent. The term inequality is related to the distribution of resources, income and standard of living among different sects of the society. Both poverty and income inequality create hurdles for economic opportunities for poor (Fukuda, 2006).

Economists and researchers are of opinion that economic reforms may be helpful in decreasing poverty and income inequality in a country. Kar (2009) and Rao (2010) suggest that socio-economic reforms strategies are useful to fight against poverty an income inequality in class ridden societies. Several reforms and efforts at the level of governments and international organizations have been introduced to eradicate poverty and income inequality (for detail see, United Nations, 200o; Todaro and Smith, 2012; Raimi and Mobolaji, 2008). Barrette and Beardmore, (2000) point out that provision of basic necessitates of life to the poor is another strategy of reducing poverty. Morduch et al. (2003) and Awojobi and Bein, (2011) state that the access to easy and soft loans through micro finance banks may be helpful in reducing poverty in developing countries and it has already shown fruitful results in Bangladesh and China.

The above discussion indicates that economic reforms can perform effective role to reduce poverty and minimizing income inequality from the society. Lustig (2015) examines the reforms in the fiscal sector by improving tax structure and spending through social safety nets to achieve the goals of reducing poverty and inequality. Several social institutions are a form of public goods which may provide opportunity to the people to make the most of their education, health, and skills. The establishment of social institutions and social spending can only be made successful through fiscal sector reforms as the income and expenditure priorities of the government are towards the weaker sections of the society.

Trade sector reforms help to overcome the phenomena of poverty by gaining comparative advantage, improving efficiency and generating employment opportunities. Getting more jobs in response to the trade reforms may have an impact on economic growth through social sector of an economy. (see for example, Anwar 2007; Neutel and Heshmati 2006; Craft 2000; Santarelli and Figini 2002; Nath and Al-Mamun 2004; Agenor 2002; Siddiqui and Iqbal 2005).

In most of the developing countries agriculture sector is a key sector for providing food and employment especially in rural areas. That is why reforms for this sector are regarded as highly important for achieving the goals of reducing poverty and income inequality. Empirical findings suggest that agricultural reforms are effective in reducing rural poverty but highly skewed lands present the reverse results (for detail see, Datt and Ravallion 1998; Timmer 1997; Thirtle 2001).

Industrial sector is considered as the back bone as well an engine for the rapid economic growth of an economy. Reforms in this sector are not only important but also necessary. Rawski (1994) analyses Chinese industrial reform accomplishments, prospects and implications. The industrial reforms in China have moved rapidly in the direction of transforming a largely planned economy into a market system. Japan, Korea, Taiwan, and Singapore have also introduced industrial reforms for reducing regulations and distortions in industrial sector.

Empirical evaluation of economic reforms and its impact on social sector of Pakistan is the main 
Review of Economics and Development Studies, Vol. 6 (2) 2020, 323-337

objective of this study. Furthermore, the study analyses and quantifies the economic reforms introduced in Pakistan in the sectors of agriculture, industry, trade, fiscal and finance. The novelty of the persent study is to quantify the economic reforms of the major sectors such as agriculture, industry, trade, fiscal and financial sector.

The organization of the study is as follows: the review of literature and theoretical frame work are presented in section 2. Section 3 explains poverty and income inequality in Pakistan along with some strategies to combat it. Section 4 describes the methodology, data sources, results and interpretations. The last section concludes.

\section{Literature Review}

Celikay and Gumus (2017) examine the relationship of the spending of social sector on poverty reduction for the period of 2004 to 2011 using Panel ECM. Long run relationship shows positive association between social spending and poverty has been observed while negative in short run. Ferrarini et al. (2016) evaluate the impact of poverty and social transfers in low, middle and high income countries. Multilevel logistic regression and cross national data has been used for forty countries. The results show that explanatory value of transfer income is greater for cross-country differences in poverty than the degree of targeting it. Qamar et al. (2016) analyze microfinance and non-monetary aspects of poverty. The expenditures on the education of the children and the actual condition of the houses are used as the main variables of non-monetary aspects. To measure the difference and significance of the variables chi-square test is applied by following binary logistic regression. The findings of the study show that micro finance has significant impact in reducing poverty and it is attained by giving better facilities in education and improving housing conditions. Zaman and Khilji (2014) investigate a the impact of economic growth on poverty reduction in different sections of a society. For this purpose annual data from 1964 to 2011 related to Pakistan economy is used for empirical analysis. The results reveal that aggregate poverty has been increased both in rural and urban sector through interaction effect. Overall impact of population shift on poverty reduction appears positive.

Cheema and Sial (2012) develop a triangle of poverty, growth and income inequality. Pooled data from eight household surveys of 1992-93 and 2007-08 is used for the study. Random effects models have been used for empirical findings. The analysis of growth elasticity of inequality of the rural and urban areas indicates that income inequality is found relatively more in urban areas as compare to rural areas.

Khan and Ahmad (2012) examine the impact of foreign investment on the policies which target the poor sections of the society for the time period from 1985 to 2011. FDI has positive relationship between economic growth but not same for pro-poor sections of the society. The study also finds that the intensity of income inequality is more than poverty reduction through foreign direct investment. Khan and Sattar (2010) evaluate the empirical piningof poverty on the economy of Pakistan form 1973 to 2009. Granger causality results show the existence of bi-directional relationships between trade and growth. Empirically analysis show positive and significant impact on economic growth both in short and long run. Foreign trade is highly important and conclusive role for reducing poverty in Pakistan.

Gillani et al. (2009) explain poverty in Pakistan particularly in relation with very important aspects of an economy as unemployment, inflation and crime. Annual data from 1975 to 2007 has been used for empirical analysis. The study concludes that poverty is the main reason for the increase in crime in Pakistan. Chaudhary et al. (2006) examine rural poverty in Pakistan and explain the 
determinants at macro level using annual data from 1963 to 1999. The results of the study show that the effects of inflation, unemployment and growth rates are positive for poverty elimination in rural areas of Pakistan. Hulme and Mosley (1996) critically analyze poverty, microenterprise and social development. The study shows that microcredit and microfinance strengthen the economy especially among low income groups. The role of micro finance and microcredit as antipoverty is questionable in South Asia. The study concludes that both microcredit and microfinance polices would be more active in poverty reduction in developing countries.

\section{Theoretical Framework}

The researchers and policy makers from developed and developing nations are agree that eradicating poverty is a huge task which requires consistent concentrated policies. They are of opinion that government should support those programs which can be helpful in increasing income and increasing social spending (see for example, Friedman, 1962; Hayek, 1960). While on the other hand, there is a very strong theoretical point of view that poverty can be reduced by introducing economic reforms through social spending in social safety nets through its public finance. Brady (2003) focuses on fiscal sector reforms for eradicating poverty and inequality. Spicker (2002) explains that targeted political choice and political decisions of a welfare state can eliminate poverty and its causes. Some studies evaluate social spending and poverty to transform a poor and weak state into welfare and developed state (see for example, Sinn, 1995; Kenworthy, 1999; Caminada and Goudswaard, 2009; Caminada et al., 2011).

Health indicators in Millennium Development Goals (MDGs) are targeted with full concentration for eradication poverty in developing countries. Life expectancy has very deep impact on poverty and is considered a major determinant for reducing poverty. Foreign inflows in an economy in shape of FDI also provide employment to the masses and hence prove helpful for removing poverty and income inequality. Torre (1985) explains the process of empowerment by providing financial support through reforming the financial sector. This empowerment can be attained by giving strength for powerless sections, enabling them to make their own decisions and may have complete control over their own affairs.

From the above discussion it can be concluded that the role of the government is indispensable for reducing poverty and income inequality. This role of the government reflects in the socio-economic reforms introduced at time to time. Furthermore, foreign direct investment, health sector reforms for reducing poverty and income inequality.

The most important strategy of the government to fight against poverty is through reforming the sick and ill-planned sectors of an economy by combining the income support programe and social spending. Economic reforms in the shape of subsidies, tax exemptions and coordinating the back bone of the economy as the sectors of agriculture, industry, trade, fiscal and financial sector may revive and generate employment opportunities and income generating economic activity. The impact of these economic reform policies and positive economic activities may diminish poverty and income inequality which is the main objective of this study.

\section{Methodology, Data and Model}

4.1 Methodology

This study is based on the development of a statistically sound methodology of index construction. Statistical information and techniques are very much important in measuring social and complex concepts of economic variables such as economic reforms. The present study has taken 
different sectors such as agriculture, industry, financial, fiscal and foreign sectors as well as their sub sectors and finally the composite outcome variable as combined economic reforms index is constructed.

The definition, construction and measurement of the desirable index is carried out on the basis of following the concept and idea of construction of Human Development Index developed by Mahbubul-Haq (1990). Moreover, Vadlamannati (2009) developed a comprehensive economic reforms index for India by following Physical Quality of Life Index (PQLI) for the period 1975 to 2006 which provides base for this study.

The procedure for the analysis of the relationship between the variables is presented below. First step of methodology is to describe the variables regarding its statistics and then unit root test is applied. Before applying ARDL bound testing is required for further estimation. For the problem of multicollinearity we apply VIF matrix. Autoregressive Distributive Lag technique is employed to find the relationship of variables both in short as well as in long run (Pesaran et al. 1999, 2001). In order to make the results robust we apply major diagnostic tests e.g. normality test, heteroskedasticity test, serial correlation and functional form test. Stability of the model is tested by cusum and cusumsq test.

\subsection{Data}

The annual time series data from 1971- 2015 for the variables foreign direct investment, population growth, life expectancy, exchange rate, age dependency ratio and gross fixed capital formation have been used from WDI. Crime data has been taken from various statistical year books. The data for economic reforms has been generated by the author. The data for social sector has been taken from Social Policy development Centre (SPDC) macroeconomic and interpolated for two years (see for example, Hyder, Ahmed and Jamal 2015).

\subsection{Model}

Poverty $=f(E R$, LIFE, FDI, EXC, LGFC)

$\mathrm{GINI}=\mathrm{f}(\mathrm{ER}, \mathrm{LGFC}, \mathrm{POPG}, \mathrm{AGE}, \mathrm{EXC}, \mathrm{LNCRIME})$

Whereas;

$\begin{array}{lll}\text { ER } & = & \text { Economic Reforms Index } \\ \text { EXC } & = & \text { Exchange rate } \\ \text { FDI } & = & \text { Foreign Direct Investment } \\ \text { LGFC } & = & \text { Log of Gross Fixed Capital } \\ \text { GINI } & = & \text { Income inequality } \\ \text { Poverty } & = & \text { Log of Poverty } \\ \text { POPG } & = & \text { Population growth } \\ \text { LNCRIME } & = & \text { Log of crime } \\ \text { LIFE } & = & \text { Life Expectancy } \\ \text { AGE } & = & \text { Age dependency Ratio }\end{array}$

\subsubsection{ARDL MODEL}

$$
\begin{aligned}
& \Delta(\operatorname{logpov})_{\mathrm{t}}=\beta_{0}+\beta_{1}(\log p o v)_{\mathrm{t}-1}+\beta_{2}(\mathrm{ER})_{\mathrm{t}-1}+\beta_{3}(\mathrm{FDI})_{\mathrm{t}-1}+\beta_{4}(L I F E)_{\mathrm{t}-1}+\beta_{5}(\mathrm{EXC})_{\mathrm{t}-1} \\
& +\beta_{6}(\mathrm{LGFC})_{\mathrm{t}-1}+\sum_{\mathrm{i}=1}^{\mathrm{n}} \delta_{\mathrm{i}} \Delta(\mathrm{ER})_{\mathrm{t}-\mathrm{i}}+\sum_{\mathrm{i}=0}^{\mathrm{n}} \varepsilon_{\mathrm{i}} \Delta(\mathrm{FDI})_{\mathrm{t}-\mathrm{i}}+\sum_{\mathrm{i}=0}^{\mathrm{n}} \psi_{\mathrm{i}} \Delta(\mathrm{LIFE})_{\mathrm{t}-\mathrm{i}} \\
& +\sum_{\mathrm{i}=0}^{\mathrm{n}} \eta_{\mathrm{i}} \Delta(\mathrm{LGFC})_{\mathrm{t}-\mathrm{i}}+\sum_{\mathrm{i}=0}^{\mathrm{n}} \gamma_{\mathrm{i}} \Delta(\mathrm{EXC})_{\mathrm{t}-\mathrm{i}}+\mathrm{U}_{\mathrm{t}}
\end{aligned}
$$




$$
\begin{aligned}
\Delta(\text { GINI })_{\mathrm{t}}= & \beta_{0}+\beta_{1}(\text { GINI })_{\mathrm{t}-1}+\beta_{2}(E R)_{\mathrm{t}-1}+\beta_{3}(\mathrm{LGFC})_{\mathrm{t}-1}+\beta_{4}(\underset{\mathrm{n} C}{\mathrm{n}})_{\mathrm{t}-1}+\beta_{5}(\text { AGE })_{\mathrm{t}-1} \\
& +\beta_{6} \mathrm{POPG}_{\mathrm{t}-1}+\beta_{7} \operatorname{lnCRIME}_{\mathrm{t}-1}+\sum_{\mathrm{i}=1}^{\mathrm{n}} \delta_{\mathrm{i}} \Delta(\mathrm{ER})_{\mathrm{t}-\mathrm{i}}+\sum_{\mathrm{i}=0}^{\mathrm{n}} \varepsilon_{\mathrm{i}} \Delta(\operatorname{lnCRIME})_{\mathrm{t}-\mathrm{i}} \\
& +\sum_{\mathrm{i}=0}^{\mathrm{n}} \theta_{\mathrm{i}} \Delta(\mathrm{AGE})_{\mathrm{t}-\mathrm{i}}+\sum_{\mathrm{i}=0}^{\mathrm{n}} \eta_{\mathrm{i}} \Delta(\mathrm{LGFC})_{\mathrm{t}-\mathrm{i}}+\sum_{\mathrm{i}=0}^{\mathrm{n}} \eta_{\mathrm{i}} \Delta(\mathrm{EXC})_{\mathrm{t}-\mathrm{i}} \\
& +\sum_{\mathrm{i}=0}^{n} \gamma_{\mathrm{i}} \Delta(\mathrm{POPG})_{\mathrm{t}-\mathrm{i}}+\mathrm{U}_{\mathrm{t}}
\end{aligned}
$$

\subsubsection{The equation of error correction:}

$$
\begin{aligned}
& \Delta(\log P o v)_{\mathrm{t}}=\beta_{0} \\
& +\sum_{\mathrm{i}=1}^{\mathrm{n}} \delta_{\mathrm{i}} \Delta(\operatorname{logpov})_{\mathrm{t}-\mathrm{i}} \sum_{\mathrm{i}=1}^{\mathrm{n}} \delta_{\mathrm{i}} \Delta(\mathrm{ER})_{\mathrm{t}-\mathrm{i}}+\sum_{\mathrm{i}=0}^{\mathrm{n}} \varepsilon_{\mathrm{i}} \Delta(\mathrm{FDI})_{\mathrm{t}-\mathrm{i}}+\sum_{\mathrm{i}=0}^{\mathrm{n}} \psi_{\mathrm{i}} \Delta(\text { LIFE })_{\mathrm{t}-\mathrm{i}} \\
& +\sum_{\mathrm{i}=0}^{\mathrm{n}} \eta_{\mathrm{i}} \Delta(\mathrm{LGFC})_{\mathrm{t}-\mathrm{i}}+\sum_{\mathrm{i}=0}^{\mathrm{n}} \gamma_{\mathrm{i}} \Delta(\mathrm{EXC})_{\mathrm{t}-\mathrm{i}}+\lambda(\mathrm{ECM})_{\mathrm{t}-1}+\mathrm{U}_{\mathrm{t}} \\
& \Delta(\mathrm{GINI})_{\mathrm{t}}=\beta_{0} \\
& +\sum_{\mathrm{i}=1}^{\mathrm{n}} \delta_{\mathrm{i}} \Delta(\mathrm{GINI})_{\mathrm{t}-\mathrm{i}}+\sum_{\mathrm{i}=1}^{\mathrm{n}} \delta_{\mathrm{i}} \Delta(\mathrm{ER})_{\mathrm{t}-\mathrm{i}}+\sum_{\mathrm{i}=0}^{\mathrm{n}} \varepsilon_{\mathrm{i}} \Delta(\operatorname{lnCRIME})_{\mathrm{t}-\mathrm{i}} \\
& +\sum_{\mathrm{i}=0}^{\mathrm{n}} \theta_{\mathrm{i}} \Delta(\mathrm{AGE})_{\mathrm{t}-\mathrm{i}}+\sum_{\mathrm{i}=0}^{\mathrm{n}} \eta_{\mathrm{i}} \Delta(\mathrm{LGFC})_{\mathrm{t}-\mathrm{i}}+\sum_{\mathrm{i}=0}^{\mathrm{n}} \eta_{\mathrm{i}} \Delta(\mathrm{EXC})_{\mathrm{t}-\mathrm{i}} \\
& +\sum_{\mathrm{i}=0}^{\mathrm{n}} \gamma_{\mathrm{i}} \Delta(\mathrm{POPG})_{\mathrm{t}-\mathrm{i}}+\lambda(\mathrm{ECM})_{\mathrm{t}-1}+\mathrm{U}_{\mathrm{t}}
\end{aligned}
$$

\section{Results and Interpretation}

Table 1 presents the results of descriptive statistics (see appendix). The kurtosis value of the coefficients i.e. economic reform, foreign direct investment, income inequality and crime are greater than 3 which show the distribution is Leptokurtic in nature. While poverty, exchange rate, life expectancy, gross fixed capital, age dependency ratio and population growth have Kurtosis values less than 3 showing they are playtykurtic in nature. The skewness value of exchange rate, poverty, gross fixed capital and population growth is near to zero showing normal skewness. While, coefficient of income inequality, economic reform, life expectancy, foreign direct investment, age dependency ratio and crime are negatively skewed. The difference between maximum and minimum values is not much showing no problem of outlier.

Table 2 Unit root Test

\begin{tabular}{|l|c|c|}
\hline \multirow{2}{*}{ Variables } & \multicolumn{2}{|c|}{ Unit Root Test } \\
\cline { 2 - 3 } & \multicolumn{2}{|c|}{ Augmented Dicky Fuller } \\
\cline { 2 - 3 } & \multicolumn{2}{|c|}{ Intercept \& Trend } \\
\hline & At Level & At First Difference \\
\hline
\end{tabular}


Review of Economics and Development Studies, Vol. 6 (2) 2020, 323-337

\begin{tabular}{|c|c|c|}
\hline & & \\
\hline ER & 3.951754 & $-3.867905^{* *}$ \\
\hline LOGPOV & -2.516058 & $-8.299763^{* * *}$ \\
\hline EXC & 0.359325 & $-1.906289^{*}$ \\
\hline FDI & $-2.736157^{*}$ & - \\
\hline LGFC & $-4.430138^{* * *}$ & $-14.96970^{* * *}$ \\
\hline GINI & -3.103294 & - \\
\hline POPG & $-5.201313^{* * *}$ & $-3.578927^{* *}$ \\
\hline Life & $-5.805620^{* * *}$ & - \\
\hline AGE & -1.640505 & $-6.059279^{* * *}$ \\
\hline LNCRIME & & \\
\hline
\end{tabular}

Table 2 explains the findings of ADF. The results of in of the unit root test reveal that there is mix order of integration. Table 3(a) and 3(b) (see appendix) show correlation within the acceptable and moderate range. The diagonal of correlation matrix from upper left to lower right always show value one because it is a correlation between the variables itself and variables must be perfectly correlated with itself. The results of VIF matrix are presented in Table 4(a) and 4(b) (see appendix) which show that all the calculated values of the regressors have the values less than 10 which confirms that the model is free from multicollinarity.

Table 5 ARDL Bound Test

\begin{tabular}{|c|c|c|}
\hline \multicolumn{3}{|c|}{ Null Hypothesis: No long-run relationships exist } \\
\hline \multicolumn{3}{|c|}{ Model 1} \\
\hline Test Statistic & Value & $\mathrm{K}$ \\
\hline F-statistic & 5.935698 & 5 \\
\hline \multicolumn{3}{|c|}{ Critical Value Bounds } \\
\hline Significance & I(o) Bound & I(1) Bound \\
\hline $10 \%$ & 2.26 & 3.35 \\
\hline $5 \%$ & 2.62 & 3.79 \\
\hline $2.5 \%$ & 2.96 & 4.18 \\
\hline $1 \%$ & 3.41 & 4.68 \\
\hline \multicolumn{3}{|c|}{ Model 2} \\
\hline Test Statistic & Value & $\mathrm{K}$ \\
\hline F-statistic & $7 \cdot 724297$ & 6 \\
\hline \multicolumn{3}{|c|}{ Critical Value Bounds } \\
\hline Significance & $\mathrm{I}(\mathrm{o})$ Bound & I(1) Bound \\
\hline $10 \%$ & 2.12 & 3.23 \\
\hline $5 \%$ & 2.45 & 3.61 \\
\hline $2.5 \%$ & 2.75 & 3.99 \\
\hline $1 \%$ & 3.15 & 4.43 \\
\hline
\end{tabular}

Table 5 illustrates the results of bound testing which demonstrates that the calculated value i.e. 5.93 of F-statistic in model 1 is higher than upper critical bound i.e. 3.35 at 1\% level of significance and in case of model 2 the calculated value i.e. 7.72 of F-statistics is higher than upper critical bound i.e. 
3.23 at $1 \%$ level of significance with the conclusion of the existence of the long run relationship of the variables.

Table 6 Results of ARDL

\begin{tabular}{|c|c|c|c|c|c|c|c|c|c|}
\hline \multicolumn{10}{|c|}{ Selected Model: ARDL(2, o, 2, 1, 2, 2) } \\
\hline \multicolumn{10}{|c|}{ Dependent Variable = Poverty } \\
\hline \multicolumn{5}{|c|}{ Long run results } & \multicolumn{5}{|c|}{ Short run results } \\
\hline $\begin{array}{c}\text { Varia } \\
\text { ble }\end{array}$ & $\begin{array}{c}\text { Coefficie } \\
\text { nt }\end{array}$ & $\begin{array}{l}\text { Std. } \\
\text { Error }\end{array}$ & t-Stat & $\begin{array}{c}\text { Pro } \\
\text { b. }\end{array}$ & Variable & $\begin{array}{c}\text { Coefficie } \\
\mathrm{nt}\end{array}$ & $\begin{array}{l}\text { Std. } \\
\text { Erro } \\
\text { r }\end{array}$ & $\begin{array}{c}\text { t- } \\
\text { Stat }\end{array}$ & $\begin{array}{c}\text { Pro } \\
\text { b. }\end{array}$ \\
\hline ER & -0.28 & 0.06 & -4.42 & $\begin{array}{c}0.0 \\
0\end{array}$ & $\mathrm{D}(\mathrm{ER})$ & -0.21 & $\begin{array}{c}0.06 \\
3 \\
\end{array}$ & $\begin{array}{c}- \\
3 \cdot 36 \\
\end{array}$ & $\begin{array}{c}0.0 \\
0\end{array}$ \\
\hline LIFE & -0.08 & 0.03 & -2.88 & $\begin{array}{c}0.0 \\
0\end{array}$ & $\mathrm{D}(\mathrm{LIFE})$ & & & & $\begin{array}{c}0.0 \\
0\end{array}$ \\
\hline FDI & 0.05 & 0.01 & 4.62 & $\begin{array}{c}0.0 \\
0\end{array}$ & $\begin{array}{l}\text { D(LIFE }(- \\
1))\end{array}$ & $\begin{array}{c}-2.81 \\
3.61 \\
\end{array}$ & $\begin{array}{l}0.85 \\
0.91 \\
\end{array}$ & $\begin{array}{l}-3 \cdot 31 \\
3.95 \\
\end{array}$ & $\begin{array}{c}0.0 \\
0\end{array}$ \\
\hline $\mathrm{EXC}$ & 0.004 & 0.00 & 3.96 & $\begin{array}{c}0.0 \\
0 \\
\end{array}$ & $\mathrm{D}(\mathrm{FDI})$ & 0.01 & 0.00 & 1.47 & 0.15 \\
\hline LGFC & 0.43 & 0.16 & 2.67 & $\begin{array}{c}0.0 \\
1 \\
\end{array}$ & $\begin{array}{c}\mathrm{D}(\mathrm{EXC}) \\
\mathrm{D}(\mathrm{EXC}(-1))\end{array}$ & $\begin{array}{c}-0.0009 \\
-0.002\end{array}$ & $\begin{array}{l}0.00 \\
0.00 \\
\end{array}$ & $\begin{array}{c}- \\
0.65 \\
-1.75 \\
\end{array}$ & $\begin{array}{c}0.51 \\
0.0 \\
9 \\
\end{array}$ \\
\hline & & & & & $\begin{array}{c}\text { D(LGFC) } \\
\text { D(LGFC(- } \\
1))\end{array}$ & $\begin{array}{c}0.17 \\
-0.16 \\
\end{array}$ & $\begin{array}{l}0.12 \\
0.10 \\
\end{array}$ & $\begin{array}{c}1.41 \\
-1.58 \\
\end{array}$ & $\begin{array}{c}0.1 \\
6 \\
0.12 \\
\end{array}$ \\
\hline $\mathrm{C}$ & 1.32 & 0.72 & 1.83 & $\begin{array}{c}0.0 \\
7 \\
\end{array}$ & $\begin{array}{l}\text { CointEq(- } \\
\text { 1) }\end{array}$ & -0.75 & 0.16 & $\begin{array}{c}- \\
4.58 \\
\end{array}$ & $\begin{array}{c}0.0 \\
0\end{array}$ \\
\hline
\end{tabular}


Review of Economics and Development Studies, Vol. 6 (2) 2020, 323-337

Table 7 Results of ARDL

\begin{tabular}{|c|c|c|c|c|c|c|c|c|c|}
\hline \multicolumn{10}{|c|}{ Selected Model: ARDL (2, o, 2, o, 2, 1, o) } \\
\hline \multicolumn{10}{|c|}{ Dependent Variable $=$ GINI } \\
\hline \multicolumn{5}{|c|}{ Long run results } & \multicolumn{5}{|c|}{ Short run results } \\
\hline Variable & $\begin{array}{l}\text { Coefficie } \\
\text { nt }\end{array}$ & $\begin{array}{l}\text { Std. } \\
\text { Erro } \\
\text { r }\end{array}$ & $\begin{array}{l}\mathrm{t}- \\
\text { Stat }\end{array}$ & $\begin{array}{l}\text { Prob } \\
.\end{array}$ & Variable & $\begin{array}{l}\text { Coefficie } \\
\text { nt }\end{array}$ & $\begin{array}{l}\text { Std. } \\
\text { Erro } \\
\text { r }\end{array}$ & $\begin{array}{l}\text { t- } \\
\text { Stat }\end{array}$ & $\begin{array}{l}\text { Pro } \\
\text { b. }\end{array}$ \\
\hline ER & -0.10 & 0.01 & 6.06 & 0.00 & $\mathrm{D}(\mathrm{ER})$ & -0.09 & 0.02 & 4.09 & $\begin{array}{r}0.0 \\
0 \\
\end{array}$ \\
\hline LGFC & 5.24 & 0.41 & $\begin{array}{r}12.6 \\
7\end{array}$ & 0.00 & $\begin{array}{c}\mathrm{D}(\mathrm{LGFC}) \\
\mathrm{D}(\mathrm{LFC})(-1))\end{array}$ & $\begin{array}{r}5.94 \\
-2.96 \\
\end{array}$ & $\begin{array}{l}1.87 \\
1.55\end{array}$ & $\begin{array}{r}3.16 \\
-1.90 \\
\end{array}$ & $\begin{array}{r}0.0 \\
0 \\
0.0 \\
6\end{array}$ \\
\hline POPG & 2.64 & 0.49 & $5 \cdot 34$ & 0.00 & D(POPG) & 2.57 & 0.61 & 4.19 & $\begin{array}{r}0.0 \\
0\end{array}$ \\
\hline AGE & -0.15 & 0.05 & $\begin{array}{r}- \\
2.89\end{array}$ & 0.00 & $\begin{array}{c}\mathrm{D}(\mathrm{AGE}) \\
\mathrm{D}(\mathrm{AGE}(-1))\end{array}$ & $\begin{array}{r}1.16 \\
0.76 \\
\end{array}$ & $\begin{array}{l}0.37 \\
0.45 \\
\end{array}$ & $\begin{array}{l}3.12 \\
1.69 \\
\end{array}$ & $\begin{array}{r}0.0 \\
0 \\
0.1 \\
0 \\
\end{array}$ \\
\hline EXC & 0.03 & 0.01 & 2.53 & 0.01 & $\mathrm{D}(\mathrm{EXC})$ & -0.01 & 0.02 & $\begin{array}{r}- \\
0.86\end{array}$ & $\begin{array}{r}0.3 \\
9 \\
\end{array}$ \\
\hline $\begin{array}{c}\text { LNCRIM } \\
\text { E }\end{array}$ & -0.27 & 0.25 & -1.09 & 0.28 & $\begin{array}{c}\text { D(LNCRIM } \\
\text { E) }\end{array}$ & -0.26 & 0.23 & -1.15 & $\begin{array}{r}0.2 \\
5 \\
\end{array}$ \\
\hline C & -13.59 & 4.95 & -2.74 & 0.01 & CointEq(-1) & -0.97 & 0.19 & $\begin{array}{r}- \\
4.94\end{array}$ & $\begin{array}{r}0.0 \\
0\end{array}$ \\
\hline
\end{tabular}

The results of model 1 are presented in Table 6 which reveals the significance of economic reform at $1 \%$ level having a negative sign both in short and long run indicating that economic reforms reduce poverty in Pakistan. The coefficient of life expectancy indicates that if life expectancy increases by $1 \%$ then poverty will reduce by 0.08 units in the long run. In case of Poverty the exchange rate coefficient is significant in the long run but insignificant in the short run. The sign of the coefficient indicates that in the long run exchange rate increases poverty in case of Pakistan. It may be due to unfavorable term of trade. Magombeyi and Odhiambo (2017) found positive impact of foreign direct investment on poverty and the present study also show the same results. The coefficient of FDI is significant and has a positive and significant impact on poverty. The long run coefficient of gross fixed capital indicates positive impact in model 1 . The results reveal that in short run the coefficient is insignificant and carries a negative sign while one period lag of gross fixed capital is negative and significant. In model 1 the coefficient of error correction term has a negative sign and is statistically significant this is an indication of convergence.

Table 7 reveals long run and short run results of model 2. The coefficient of economic reforms is negative and highly significant in short run and long run. The negative sign indicates that economic reform reduces income inequality in Pakistan both in long and short run. In case of income inequality the coefficient of gross fixed capital carries a +ve sign with significance in both short and long run indicating that gross fixed capital increases income inequality in Pakistan. The coefficient of population growth shows positive and significant impact on income inequality indicating that population growth increases income inequality in the long run and short run. Age dependency ratio reduces income 
Review of Economics and Development Studies, Vol. 6 (2) 2020, 323-337

inequality in the long run but in the short run it has a positive and significant impact on income inequality. The coefficient of crime is negative and insignificant both in short and long indicating that the role of crime in income inequality is not indispensable in Pakistan. In model 2 the value of ECM is negative and significant which is an indication of convergence.

Table 8 Diagnostic Test

\begin{tabular}{|l|l|l|}
\hline \multicolumn{2}{|c|}{ Model 1 } \\
\hline Item & Test Applied & P- values \\
\hline Normality Test & Jarque-Bera & 0.46 \\
\hline Serial correlation & LM Test & 0.11 \\
\hline Heteroscedasticity & White test & 0.19 \\
\hline Functional Form & Ramsey Reset Test & 0.15 \\
\hline \multicolumn{2}{|c|}{ Model 2 } \\
\hline Item & Test Applied & P- values \\
\hline Normality Test & Jarque-Bera & 0.77 \\
\hline Serial correlation & LM Test & 0.35 \\
\hline Heteroscedasticity & White test & 0.12 \\
\hline Functional Form & Ramsey Reset Test & 0.27 \\
\hline
\end{tabular}

To confirm robustness of the results various diagnostic test have been employed in this study. In Table 8 the results of the diagnostic test reveal that both models are free autocorrelation, hetrosaedasticity, normality problem and wrong functional form. Plot of cusum and cusum square are presented in figure 1 and 2 which reveal that both models are stable.

\section{Model 1}

Model 2
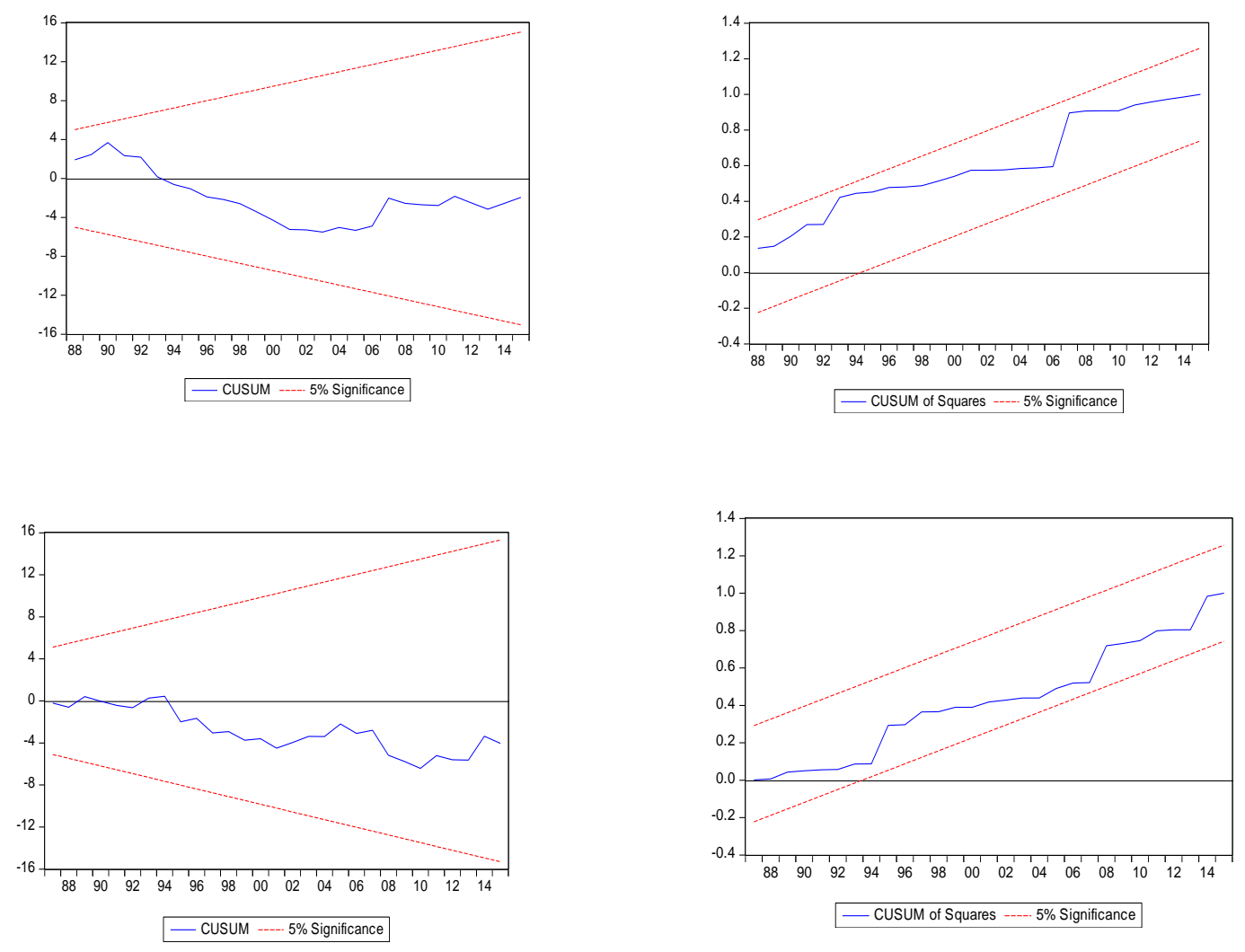


\section{Review of Economics and Development Studies, Vol. 6 (2) 2020, 323-337}

\section{Conclusion and Policy Recommendations}

Poverty reduction and income inequality have always been given a priority by social development policy which indicates the impact of economic reforms on social sector of Pakistan. The major findings of the study reveal that due to economic reforms in Pakistan poverty and income inequality have dwindled both in the long and short run. In the short run, the $e c m_{t-1}$ term of both model are negative and statistically significant which shows convergence of the models.

The government must shows its firm commitment to effective implementation of social protection and poverty alleviation strategies after having gross root level scientific surveys of poverty. Furthermore, pro-poor spending policies should be formulated especially in health sector through socioeconomic reform strategies. The policies must be targeted through investing in low income groups, providing them better health facilities and helping in improving living standards. Public sector development program should be pro-poor growth strategy oriented and foreign direct investment shows integration to the public sector development program targeting employment enhancing opportunities. Furthermore, low level of inequality among the sections of society may also have positive impact because it generates competition but the suggested policy is to reduce inequality or at least check it from rising through taxes and subsidies, respectively. The present government of Pakistan has taken several effective steps in reducing poverty and improving living standard by providing subsidized services in the sector of health and education.

\section{References}

Agénor, P. R. (2002). Does globalization hurt the poor?. The World Bank.

Anwar, T., \& Qureshi, S. K. (2002). Trends in absolute poverty in Pakistan: 1990-91 and 2004-05. Pakistan Development Review, 41(4 Part II), 859-878

Asad, M. A., \& Ahmad, M. (2011). Growth and consumption inequality in Pakistan. Pakistan Economic and Social Review, 69-89.

Awojobi, O., \& Bein, M. A. (2011). Microfinancing for Poverty Reduction and Economic Development; a Case for Nigeria. International Research Journal of Finance and Economics (72), 159-168.

Barrette, A. J., \& Beardmore, R. M. (2000). India's urban poverty agenda: understanding the poor in cities and formulating appropriate anti-poverty actions. A discussion paper for South Asia and City Management Course, Washington, DC.

Brady, D. (2003). The poverty of Liberal Economics, Socio-Economic Review, 1(3), 369-409, https://doi.org/10.1093/soceco/1.3.369

Caminada, K., \& Goudswaard, K. (2009). Effectiveness of poverty reduction in the EU: A descriptive analysis. Poverty \& Public Policy, 1(2), 1-49.

Caminada, M., Pigozzi, G., \& Podlaszewski, M. (2011). Manipulation in group argument evaluation. In Twenty-Second International Joint Conference on Artificial Intelligence.

Celikay, F., \& Gumus, E. (2017). The effect of social spending on reducing poverty. International Journal of Social Economics, 44(5), 620-632.

Chambers, R. (2006). 'What is poverty? Who asks? Who answers?' In Poverty in focus: What is poverty? Concepts and Measures. UNDP, International Poverty Centre. http://www.undppovertycentre.org

Chaudhry, I. S., Malik, S., \& Ashraf, M. (2006). Rural poverty in Pakistan. Pakistan Economic and Social Review, 44(2), 259-276.

Cheema, A. R., \& Sial, M. H. (2012). Poverty, income inequality, and growth in Pakistan: A pooled regression analysis. The Lahore Journal of Economics 17 (2), 137-157

Cizakca, M. (2004). Cash waqf as alternative to NBFIs Bank. In International Seminar on Nonbank Financial Institutions: Islamic Alternatives (pp. 1-3). 


\section{Review of Economics and Development Studies, Vol. 6 (2) 2020, 323-337}

Cotterill, S. J., Ahrens, S., Paulussen, M., Jurgens, H. F., Voute, P. A., Gadner, o. H., \& Craft, A. W. (2000). Prognostic factors in Ewing's tumor of bone: analysis of 975 patients from the European Intergroup Cooperative Ewing's Sarcoma Study Group. Journal of clinical oncology, 18(17), 31083114 .

Datt, G., \& Ravallion, M. (1998). Farm productivity and rural poverty in India. The Journal of Development Studies, 34(4), 62-85.

Ferrarini, T., Nelson, K., \& Palme, J. (2016). Social transfers and poverty in middle-and high-income countries-A global perspective. Global Social Policy, 16(1), 22-46.

Frankel, J. A., \& Romer, D. H. (1999). Does trade cause growth?. American economic review, 89(3), 379399.

Friedman, H. L. (1962). Ionic Solution Theory: based on Cluster expansion methods (Vol. 3). Interscience Publishers.

Fukuda-Parr, S. (2006). Millennium development goal 8: Indicators for international human rights obligations. Hum. Rts. Q., 28, 966.

Gillani, S. Y. M., Rehman, H. U., \& Gill, A. R. (2009). Unemployment, poverty, inflation and crime nexus: Cointegration and causality analysis of Pakistan. Pakistan Economic and Social Review, 79-98.

Gillespie, D., Ahmed, S., Tsui, A., \& Radloff, S. (2007). Unwanted fertility among the poor: an inequity?. Bulletin of the World Health Organization, 85, 100-107.

Hollowell, J., Oakley, L., Kurinczuk, J. J., Brocklehurst, P., \& Gray, R. (2011). The effectiveness of antenatal care programmes to reduce infant mortality and preterm birth in socially disadvantaged and vulnerable women in high-income countries: a systematic review. BMC pregnancy and childbirth, 11(1), 13.

Hulme, D., \& Mosley, P. (1996). Finance against poverty (Vol. 1, No. 2). London: Routledge.

Hulme, D., \& Mosley, P. (1996). Finance for the Poor Or Poorest?: Financial Innovation, Poverty and Vulnerability. University of Reading, Department of Economics and Department of Agricultural Economics.

Iqbal, Z., \& Sattar, A. (2010). The contribution of workers' remittances to economic growth in Pakistan. Working Papers \& Research Reports, RR-No.

Irz, X., Lin, L., Thirtle, C., \& Wiggins, S. (2001). Agricultural productivity growth and poverty alleviation. Development policy review, 19(4), 449-466.

Jefferson, G. H., \& Rawski, T. G. (1994). How industrial reform worked in China: the role of innovation, competition, and property rights. The World Bank Economic Review, 8(1), 129-156.

Khan, J. H., Hassan, T., \& Shamshad. (2014). Incidence of poverty and level of socio-economic deprivation in India. The Journal of Developing Areas, 21-38.

Lazear, E. P., \& Oyer, P. (2004). Internal and external labor markets: a personnel economics approach. Labour economics, 11(5), 527-554.

Littlefield, E., Morduch, J., \& Hashemi, S. (2003). Is microfinance an effective strategy to reach the millennium development goals?. Focus note, 24(2003), 1-11.

Lustig, N., (2015). The redistributive impact of government spending on education and health: evidence from 13 developing countries in the Commitment to Equity project.

Gupta, S., Keen, M., Clements, B., de Mooij, R. (Eds.), Inequality and Fiscal Policy. International Monetary Fund, Washington, D.C.

Marjit, S., \& Kar, S. (2009). A contemporary perspective on the informal labour market: theory, policy and the Indian experience. Economic and Political weekly, 60-71.

Mohsin, M. I. A. (2013). Potential of zakat in eliminating riba in and eradicating Muslim countries. EJBM-Special Issue: Islamic Management and Business, 5(11),114-126.

Murgai, R., \& Ravallion, M. (2005). Employment guarantee in rural India: What would it cost and how 
much would it reduce poverty?. Economic and Political Weekly, 3450-3455.

Nath, H. K., \& Al Mamun, K. A. (2004). Trade liberalization, growth and inequality in Bangladesh: an empirical analysis. In This paper was presented at the 41st Annual Conference of the Missouri Valley Economic Association held in October.

Neutel, M., \& Heshmati, A. (2006). Globalisation, inequality and poverty relationships: a cross country evidence. IZA Discussion Paper No. 2223.

Raimi, L., \& Mobolaji, H. I. (2008). Imperative of economic integration among Muslim countries: Lessons from European globalisation. Humanomics, 24(2), 130-144.

Rao, S., \& Sharma, D. R. (2010). Bank selection criteria employed by MBA students in Delhi: an empirical analysis. Journal of business studies Quarterly, 1(2), 56-69.

Santarelli, E., \& Figini, P. (2002). Does globalization reduce poverty. Università di Bologna, http://amsacta. cib. unibo. it/archive/ooooo633/o1/459.

Sattar, R., \& Khan, R. E. A. (2010). Trade Growth and Poverty: A Case of Pakistan. The Islamia University of Bahawalpur Department of Economics Working Paper, (2010/01).

Schultz, T. W. (1961). Investment in human capital. The American economic review, 1-17.

Seccombe, K. (2000). Families in poverty in the 1990s: Trends, causes, consequences, and lessons learned. Journal of Marriage and Family, 62(4), 1094-1113.

Shaikh, A. (2007). A proposed synthesis of Classical and Keynesian growth. The New School for Social Research, Working Paper, (5).

Timmer, C. P. (1997). How well do the poor connect to the growth process?. Harvard Institute for International Development.

Todaro, Michael P. and Smith, Stephen C. (2012), Economic development, 11thed. pp.; 202-265, Published by Addison-Wesley, United States of America.

Zaman, K., \& Khilji, B. A. (2014). Sectoral decomposition of changes in Pakistan's poverty: the new interface. Journal of Poverty, 18(4), 453-476.

Zaman, K., Khan, M. M., \& Ahmad, M. (2012). The relationship between foreign direct investment and pro-poor growth policies in Pakistan: The new interface. Economic Modeling, 29(4), 1220-1227 


\section{Appendix}

Table 1: Descriptive Statistics

\begin{tabular}{|c|c|c|c|c|c|c|c|c|c|c|}
\hline & ER & EXC & FDI & LGFC & GINI & LOGPOV & POPG & LNCRIMES & LIFE & AGE \\
\hline Mean & 0.19 & 39.05 & 0.74 & 11.33 & 35.54 & 1.50 & 2.74 & 12.43 & 60.56 & 83.59 \\
\hline Median & 0.08 & 28.11 & 0.54 & 11.41 & 36.65 & 1.49 & 2.79 & 12.65 & 60.90 & 87.25 \\
\hline Maximum & 0.96 & 102.77 & 3.37 & 12.59 & 37.40 & 1.71 & 3.36 & 13.42 & 66.32 & 89.37 \\
\hline Minimum & 0.00 & 4.76 & -0.07 & 9.83 & 28.50 & 1.37 & 2.09 & 8.68 & 53.39 & 67.35 \\
\hline Std. Dev. & 0.27 & 30.29 & 0.78 & 0.80 & 2.39 & 0.08 & 0.40 & 0.98 & 3.73 & 6.80 \\
\hline Skewness & 1.64 & 0.72 & 1.96 & -0.19 & -1.41 & 0.65 & -0.16 & -2.00 & -0.22 & -1.22 \\
\hline Kurtosis & 4.53 & 2.26 & 6.59 & 2.00 & 3.88 & 2.87 & 1.81 & 7.33 & 1.92 & 2.99 \\
\hline Observations & 45 & 45 & 45 & 45 & 45 & 45 & 45 & 45 & 45 & 45 \\
\hline
\end{tabular}

Table 3 (a) correlation Matrix

\begin{tabular}{|l|r|l|r|r|r|}
\hline & \multicolumn{1}{|l|}{ LGFC } & \multicolumn{1}{l|}{ COMIND } & LIFE & FDI & EXC \\
\hline LGFC & 1 & & & & \\
\hline COMIND & -0.138526601 & 1 & & & \\
\hline LIFE & -0.216048796 & 0.798332074 & 1 & & \\
\hline FDI & -0.07523231 & 0.355916519 & 0.592541196 & 1 & \\
\hline EXC & -0.18816143 & 0.930437283 & 0.930528652 & 0.479310268 & \\
\hline
\end{tabular}

Table 3 (b) correlations Matrix

\begin{tabular}{|c|c|c|c|c|c|c|}
\hline & COMIND & LGFC & DAGE & POPG & EXC & LNCRIMES \\
\hline COMIND & 1 & & & & & \\
\hline LGFC & 0.8064101 & 1 & & & & \\
\hline DAGE & 0.6343384 & -0.81 & 1 & & & \\
\hline POPG & -0.8312792 & -0.8 & 0.74 & 1 & & \\
\hline EXC & 0.9304373 & 0.929 & -0.8 & -0.90698 & 1 & \\
\hline LNCRIMES & 0.6244114 & 0.906 & -0.7 & -0.55071 & 0.750665 & 1 \\
\hline
\end{tabular}

Table 4(a) VIF Matrix

\begin{tabular}{|l|r|r|r|r|r|}
\hline & \multicolumn{1}{l|}{ LGFC } & \multicolumn{1}{l|}{ COMIND } & \multicolumn{1}{l|}{ LIFE } & FDI & EXC \\
\hline LGFC & 1 & & & & \\
\hline COMIND & 1.019565065 & 1 & & & \\
\hline LIFE & 1.048962509 & 2.757358774 & 1 & & \\
\hline FDI & 1.005692117 & 1.14505115 & 1.54108154 & & 1 \\
\hline EXC & 1.036704227 & 7.446767021 & 7.456208145 & 1.298260114 & \\
\hline
\end{tabular}


Review of Economics and Development Studies, Vol. 6 (2) 2020, 323-337

Table 4(b) VIF Matrix

\begin{tabular}{|l|r|r|r|r|r|r|}
\hline & \multicolumn{1}{l|}{ COMIND } & LGFC & AGE & POPG & EXC & LNCRIMES \\
\hline COMIND & 1 & & & & & \\
\hline LGFC & 2.8595713 & 1 & & & & \\
\hline AGE & 1.6733186 & 2.892 & 1 & & & \\
\hline POPG & 3.2365089 & 2.732 & 2.19 & 1 & & \\
\hline EXC & 7.446767 & 7.33 & 2.94 & 5.637257 & 1 & \\
\hline LNCRIMES & 1.6390476 & 5.591 & 1.92 & 1.435297 & 2.290936 & 1 \\
\hline
\end{tabular}

